\title{
ECOPRENEURSHIP DALAM MENUMBUHKAN USAHA BERWAWASAN LINGKUNGAN PADA SENTRA INDUSTRI PENYAMAKAN KULIT SUKAREGANG KABUPATEN GARUT
}

\author{
Iwan Sukoco dan Herwan Abdul Muhyi \\ (Dosen Administrasi Bisnis Fisip Unpad) \\ Email :wansukoco@yahoo.co.id dan herwan_am@yahoo.com
}

\begin{abstract}
ABSTRAK. Sentra Industri Penyamakan Kulit Sukaregang ini terletak tidak jauh dari Kota Garut dan berdampingan dengan masyarakat atau pemukiman penduduk. Kondisi ini menimbulkan dua efek besar dalam kehidupan penduduk sekitar. Pertama: Menurut penduduk sekitar, industri penyamakan kulit di kawasannya merupakan berkah sebagai mata pencaharian utama. Sebagian besar tenaga kerja yang ada terserap menjadi karyawan di sentra industri ini. Kedua, Penduduk juga mengeluhkan akan pencemaran yang sangat mengganggu kualitas lingkungan tempat mereka hidup, diantaranya adalah pencemaran udara yang sangat menyengat dan mengganggu pernafasan. Selain itu juga pencemaran air sungai sebagai dampak dari limbah yang tidak terkelola dengan baik oleh para pelaku industri penyamakan kulit. Penelitian ini menggunakan metode penelitian kualitatif. Informasi diperoleh melalui wawancara mendalam, observasi, FGD, studi literatur dan analisis data sekunder.Penelitian ini menunjukan kondisi yang unik bagi penduduk Sukaregang, disatu sisi mereka mengandalkan industri sebagai sumber pencaharian, disisi lain menjadi sumber pencemaran udara dan air yang menurunkan kualitas lingkungan hidup mereka.Berbagai penelitian mengenai pertumbuhan usaha lebih menekankan pada aspek pertumbuhan usaha semata tanpa meneliti aspek lingkungan. Sedangkan pada penelitian ini digali bagaimana seorang wirausaha berupaya menumbuhkan usahanya dengan mempertimbangkan aspek lingkungan sebagai faktor penting dalam menjalankan usaha, yang dikenal sebagai ecopreneurship. Pertumbuhan usaha diharapkan dapat berkelanjutan seiring dengan terpeliharanya kualitas lingkungan hidup.Sebagian besar pengusaha Sukaregang belum sepenuhnya mampu untuk menerapkan jiwa wirausaha berwawasan lingkungan (ecopreneurship) dalam menjalankan usahanya. Hal ini dikarenakan dalam pengolahan limbah yang baik dan benar membutuhkan biaya yang besar. Pertumbuhan penjualan yang terjadi di sentra industri kulit Sukaregang kian meningkat dan terus berkembang, yang mengindikasikan adanya pertumbuhan usaha.
\end{abstract}

Kata Kunci : Ecopreneurship, Pertumbuhan Usaha, Kualitas Lingkungan

\section{ECOPRENEURSHIP IN GROWING BUSINESS WITH ENVIRONMENTAL INSIGHT IN TANNERY INDUSTRIAL CENTER OF SUKAREGANG, GARUT DISTRICT}

ABSTRACT. Tannery Industrial Center of Sukaregang is located not far from the city of Garut and side by side with people residential. These conditions cause two major effects in the lives of local people. First: According to nearby residents, leather tanning industry in the region was a blessing as the main livelihood. Most of the existing workforce absorbed into the employees in the industrial district. Second, residents also complained that pollution will greatly disturb the quality of the environment in which they live, such as air pollution is very pungent and interfere with breathing. In addition, river water pollution as a result of the waste that is not managed properly by the leather tanning industry. This resesearch used qualitative research method. Information was obtained by in-depth interview, observation, focussed group discussion, literature study and secondary data analyses. This research indicate a unique conditions for Sukaregang citizens, on one hand, they rely on the industry as a source of income, on the other hand a source of air and water pollution that degrade the quality of their living environment. Various studies on the growth of businesses are more emphasis on business growth alone without examining the environmental aspects. While in this study will be explored how an entrepreneur will seek to grow its business by considering aspects of the environment as an important factor in running a business, which is known as ecopreneurship. Growth is expected to be an ongoing effort as the maintenance environmental quality. Most employers of Sukaregang not fully able to implement ecopreneurship in their business. This is because in the processing of proper waste treatment need high cost. Sales growth is occurring in the center of the leather industry Sukaregang indicates the business growth in tannery industrial center of Sukaregang, Garut.

Keywords : Ecopreneurship , Business Growth, Environmental Quality

\section{PENDAHULUAN}

Kabupaten Garut merupakan salah satu daerah yang berada di wilayah Provinsi Jawa Barat. Kabupaten ini memiliki potensi alam yang sangat menarik, misalnya wisata alam Cipanas yang menjadi magnet bagi para wisatawan dari berbagai daerah di Indonesia bahkan mancanegara.

Kondisi ini merupakan potensi yang berimbas pada berbagai sektor perekonomian di Kabupaten Garut. Oleh-oleh baik berupa makanan maupun produk sandang menjadi idola dalam menggenjot perekonomian daerah. Salah satu produk sandang yang sangat terkenal dari Kabupaten Garut adalah berbagai produk dari bahan kulit binatang. Hasil produknya berupa: tas, sabuk, tali jam tangan, dompet dan lain-lain. Hasil peroduknya bukan hanya dipasarkan di wilayah Garut saja melainkan sudah menyebar ke berbagai negara tujuan ekspor.

Mayoritas pengrajin yang bergelut dibidang industri kulit ini terpusat di sentra Industri Penyamakan Kulit Sukaregang Kabupaten Garut. Sentra Industri Penyamakan Kulit Sukaregang ini 
terletak tidak jauh dari Kota Garut dan berdampingan dengan masyarakat atau penduduk sekitarnya. Kondisi ini menimbulkan dua efek besar dalam kehidupan penduduk sekitar. Pertama, menurut penduduk sekitar, industri penyamakan kulit di kawasannya merupakan berkah sebagai mata pencaharian utama. Sebagian besar tenaga kerja yang ada terserap menjadi karyawan di sentra industri ini. Kedua, penduduk juga mengeluhkan akan pencemaran yang sangat mengganggu kualitas lingkungan tempat mereka hidup, diantaranya adalah pencemaran udara yang sangat menyengat dan mengganggu pernafasan. Selain itu juga pencemaran air sungai sebagai dampak dari limbah yang tidak terkelola dengan baik oleh para pelaku industri penyamakan kulit. Kondisi ini menjadi buah simalakama bagi penduduk Sukaregang, di satu sisi mereka mengandalkan industri sebagai sumber pencaharian, di sisi lain menjadi sumber pencemaran udara dan air yang menurunkan kualitas lingkungan hidup mereka.

Schaper (2002:3) mengutip pendapat Bennett, Berle dan Blue yang mengemukakan konsep ecopreneur sebagai berikut:, "beginning to employ the terms 'environmental entrepreneur', 'green entrepreneur, 'ecoentrepreneur' and its derivation 'ecopreneur.'

Dari konsep tersebut, dapat diartikan bahwa ecopreneurship berasal dari kata environmental dan entrepreneur. Artinya gabungan dari istilah lingkungan dan wirausaha. Secara harfiah dapat dikatakan bahwa ecopreneurship merupakan wirausaha yang berwawasan lingkungan dalam menjalankan usahanya. Secara tradisional, manajemen bisnis yang berwawasan lingkungan berfokus pada upaya bagaimana perusahaan yang ada menjadi lebih hijau (green corporate). Banyak sekali menyita waktu dan upaya untuk mewujudkan perusahaan menjadi tumbuh secara berkelanjutan dan bertanggung jawab terhadap keberlangsungan lingkungan hidup.

Schaper (2002:4) mengemukakan tentang bagaimana kebijakan dapat mendorong para entrepreneur memperhatikan perusahaannya supaya lebih hijau :

"Legislation, governmentregulation and industrisupport agencies all have a role to play in shaping the way that business conducts its activities. Other stakeholders, such as lobby groups, non-governmental organisations (NGOs), venture capitalists, industri associations and local communities can also influence the context in which ecopreneurs operate. How can the activities of these bodies be encouraged to foster environmental entrepreneurs?"

Pernyataan tersebut menggambarkan bahwa konsep green entrepreneur merupakan tanggung jawab dari semua stakeholders dalam mewujudkannya. Schaltegger .(2002:2) mengemukakan :

"ecopreneurs differ from conventional entrepreneurs in that they also build bridges between environmental progress and market success."... To make sure that eco-efficiency gains are not counteracted by higher production, ecopreneurs must also focus on eco-efficacy. Eco-efficacy describes how well the reduction of environmental impacts is achieved in absolute terms."
Pendapat Schaltegger tersebut mengisyaratkan bahwa seorang ecopreneur adalah pengusaha yang mampu menyeimbangkan antara pertumbuhan usaha dan perkembangan lingkungan hidup. Seorang entrepreneur harus mampu mereduksi atau meminimalisis dampak negatif dari operasi usahanya terhadap keberlangsungan lingkungan hidup.

Berbagai penelitian tentang pertumbuhan usaha sebenarnya pernah dilakukan oleh para peneliti seperti tertera di bawah ini:

1. Askiah Jamaluddin dan Carolyn Dickie (2011:10) dengan judul "Decision-making Related to Business Growth: Malay Small Business in Selangor". Penelitian ini bertujuan untuk mengembangkan fakta-fakta mengenai bisnis keluarga, dengan memfokuskan strategi pengambilan keputusan yang dibuat untuk mengembangkan bisnis,

2. Adapun Johan Wiklund, Holger Patzelt, dan Dean A. Shepherd (2009) dengan judul "Building an Integrative Model of Small Business Growth". Tujuan dari penelitian ini yaitu untuk mengembangkan sebuah model integratif dari bisnis kecil,

3. Paul J. A. Robson dan Robert J. Bennett (2000, 193-208) meneliti usaha kecil dan menengah dengan judul "SME Growth: The Relationship with Business Advice and External Collaboration”.

Penelitian-penelitian tersebut lebih menekankan pada aspek pertumbuhan usaha semata tanpa meneliti aspek lingkungan. Sedangkan pada penelitian ini akan digali bagaimana seorang wirausaha akan berupaya menumbuhkan usahanya dengan mempertimbangkan aspek lingkungan sebagai faktor penting dalam menjalankan usaha.

Penelitian ini akan menggali interface antara entrepreneur dengan lingkungan hidup yang menjadi domain ekologi. Pertumbuhan usaha diharapkan dapat berkelanjutan seiring dengan terpeliharanya kualitas lingkungan hidup.

\section{METODE PENELITIAN}

\section{Objek Penelitian}

Objek penelitian pada penelitian ini adalah ecopreneurship industri penyamakan kulit yang berada di Sentra Industri Penyamakan Kulit di Sukaregang Kabupaten Garut. Sentra industri kulit ini berada di wilayah penduduk Desa Sukaregang Kecamatan Garut Kota Kabupaten Garut.

\section{Desain Penelitian}

Penelitian akan dilakukan dengan menggunakan pendekatan kualitatif. Diharapkan dengan menggunakan pendekatan ini, penulis akan menggali lebih dalam mengenai kondisi riil yang terjadi dalam pengelolaan industri penyamakan kulit dikaitkan dengan pertumbuhan usaha yang berwawasan lingkungan.

Adapun teknik pengumpulan data adalah sebagai berikut :

1. In-depth interview. Penulis lakukan dengan para informan yang dianggap paling mengetahui mengenai penelitian ecopreneurship dan pertumbuhan usaha 
berwawasan lingkungan. Kami himpun data dari sisi pengusaha, baik pengrajin maupun penyamak, dari sisi pemerintah setempat, hingga masyarakat desa sekitar Desa Sukaregang Kecamatan Garut Kota Kabupaten Garut.

2. Observasi lapangan. Peneliti akan melakukan observasi dengan mencari data dan informasi mengenai implementasi kebijakan langsung ke lapangan, berlokasi di Sukaregang Kabupaten Garut.

3. Focussed Group Discussion.FGD akan dilakukan dengan melibatkan semua pihak terkait baik masyarakat/penduduk Sukaregang, Pemerintah Kabupaten Garut, Tokoh masyarakat, akademisi dan para pelaku industri penyamakan kulit.

4. Studi literatur. Akan penulis lakukan dengan mengkaji berbagai teori ecopreneurship dan lingkungan hidup.

5. Pengumpulan data sekunder baik dari pihak dinas terkai di Kabupaten Garut maupun para pengusaha yang melakukan praktik di Sukaregang Garut.

Data yang diperoleh akan diuji dengan melakukan triangulasi ke semua sumber data yang dianggap terkait dengan permasalahan dan topik penelitian. Selanjutnya akan disajikan secara sistematis dengan deskripsi yang jelas dan terhadap data dan informasi yang diperoleh.

\section{Analisis Data}

Analisis data adalah suatu proses pengorganisasian dan mengurutkan data ke dalam pola, kategori, dan satuan uraian dasar sehingga dapa ditemukan tema dan dapat dirumuskan hipotesis kerja. Sebagai implementasi peneliti mengumpulkan data sesuai dengan masalah penelitian melalui observasi, interview dan dokumentasi.

\section{HASIL PENELITIAN DAN PEMBAHASAN}

Kulit merupakan salah satu jenis hasil ternak yang sekarang ini telah dijadikan sebagai suatu komoditi perdagangan dengan harga yang cukup tinggi. Nilai ekspor yang tinggi ini dapat memberi keuntungan yang cukup baik bagi industri kulit yang ada di Indonesia, hal ini yang mendorong industri pengolahan kulit sekarang ini banyak bermunculan dan berkembang dengan pesat.

\section{Pertumbuhan Usaha Berkelanjutan (Sustained Business Growth) Industri Penyamakan Kulit Sukaregang}

Penelitian ini membahas secara mendalam mengenai ecopreneurship yang dimiliki oleh para pengusaha penyamakan kulit di Sentra Industri Sukaregang. Terkait dengan entrepreneurship yang berwawasan lingkungan (ecopreneurship) ada beberpa hal yang utama yang dibahas dalam penelitian ini. Pertama, bagaimana kondisi pertumbuhan industri baik dari segi jenis, kuantitas dan tingkat penjualan yang diperoleh para pengusaha penyamakan kulit di sentra industri ini. Kedua, apakah kondisi pertumbuhan bisnis seiring dengan pemeliharaan lingkungan hidup di sentra industri penyamakan kulit Sukaregang.

Dari segi jenis usaha dengan bahan dasar kulit, ada dua jenis usaha yaitu : i). Penyamakan kulit, berada di area belakang Sukaregang. Usaha ini memproduksi industri kulit dari kulit mentah hingga produk seperempat atau setengah jadi, dan pada penyamakan ini ada proses basah dan proses kering. ii). Pengrajin kulit, berada di sektor depan Sukaregang. Jenis usaha ini dmembuat produl dari bahan setengah jadi hingga bahan jadi, seperti tas, jaket, sepatu, sabuk, dan lain-lain.

Usaha penyamakan kulit merupakan usaha penyediaan bahan baku garmen seperti jaket, sepatu, sarung tangan dan segala assesoris yang melekat di tubuh dari bahan kulit terutama sapi, kerbau, kambing dan domba. Penyamakan kulit disebut juga industri hulu, sebab, pembuatannya hingga menjadi barang siap pakai dikelola orang jenis usaha yang kedua atau kerap disebut sebagai bagian usaha hilir.

Pengrajin yang bergerak dalam pengolahan kulit memproduksi kulit menjadi makanan dan non makanan. Produk makanan yang berasal dari kulit seperti kerupuk kulit, kerupuk dorokdok, kerupukdengkul, kerecek, sate kulit, dan lain sebagainya. Produk non makananyang berbahan baku kulit seperti produk pakaian (jaket, baju, rok, celana,sepatu, tas, sabuk, dll), perlengkapan olah raga (bola, sarung tangan golf, dll), perlengkapan otomotif (sarung jok, interior mobil, dll), perlengkapan kerja (jaket pengaman, safety shoes, chamois, belt, dll), dan lain sebagainya.

Potensi usaha yang begitu prospektif tersebut akan terus berkembang apabila para pengusaha (entrepreneur) mampu meningkatkan pertumbuhan usaha dari waktu ke waktu secara berkelanjutan. Pertumbuhan menjadi kunci sukses perusahaan untuk terus berkembang.

Pertumbuhan usaha merupakan harapan setiap pengusaha yang menunjukkan kesuksesan dalam menjalankan usaha."Tahap kesuksesan suatu perusahaan akan menunjukkan pertumbuhan kinerja keuangan secara konsisten, biasanya disertai peningkatan penjualan yang tidak terlalu cepat “ (Katz and Green II, 2011:639).

Sebagai contoh, PT ELCO yang memulai usaha sejak 1992 hingga terus berkembang saat ini adalah salah satu contoh pengusaha yang masuk dalam kategori ini.

Perusahaan pada masa pertumbuhan membangun informasi, kemampuan, dan aktivitas rutin lainnya untuk menumbuhkan keuntungan bisnis. Keuntungan itu tidaklah selalu dalam bentuk uang.

"Tersedianya waktu untuk libur dari pekerjaan, kerja yang lebih santai, merekrut pegawai tambahan untuk membantu melakukan pekerjaan pengusaha merupakan keuntungan-keuntungan yang membuat kehidupan pengusaha (owner) lebih mudah." (Katz and Green II, 2011:639).

PT ELCO, sebagai contoh perusahaan kulit yang terus mengalami pertumbuhan. Berdasarkan informasi, perusahaan ini memiliki 200 orang kaeryawan dengan laba bersih mencapai Rp 120 juta sebulan dan telah memiliki 12 gerai yang menjual 
jaket kulit, menjadi salah satu pengusaha yang masuk dalam kategori tumbuh secara kontinyu..

Pertumbuhan usaha ditunjukkan dengan kecenderungan membesarnya operasi usaha secara signifikan. Hal ini dikemukakan oleh Peter Wilson dan Sue Bates (2003:12): "Growth mean a business that demonstrates (or shows visible signs of) a propensity to expand operations significantly."

Merintis usaha merupakan suatu tantangan tersendiri, dan akan lebih terasa ketika menjalankan dan mengembangkannya. Pada tahun-tahun pertama berdiri, sedikit kemajuan yang menunjukkan pertumbuhan merupakan sesuatu yang sangat diharapkan oleh para pengusaha.

Pertumbuhan yang diharapkan adalah pertumbuhan yang terus menerus, bukan hanya tumbuh ketika awal merintis. Inilah fase-fase sulit seorang wirausaha. Banyak wirausaha merintis dan menjalankan usaha dan hanya tumbuh pada hitungan satu tahun atau bahkan dalam hitungan bulan.

Kita ambil kembali PT ELCO sebagai contoh, yang mana pada awal terbentuknya usaha, PT ELCO mengajukan modal pinjaman dari Lembaga Permodalan PT Sarana Jabar Ventura, dengan modal awal ratusan juta rupiah dan kini berkembang dengan jumlah omzet miliaran rupiah.

Pertumbuhan usaha yang terus menerus dalam kurun waktu tertentu atau berkelanjutan merupakan parameter keberhasilan wirausaha dalam merintis dan mengelola usaha. Barringer, et al (2010:450) mengemukakan bahwa, "Sustained Business growth, which is growth in both revenues and profits over a sustained period of time."

Suatu pertumbuhan dikatakan berkelanjutan kuncinya adalah ada periode waktu yang terus menerus (sustained period of time). Dengan demikian mengukur berkelanjutan tidak cukup hanya menilai 1 (satu) tahun saja akan tetapi harus dalam kurun tahun tertentu yang akan menunjukkan pertumbuhan yang berkelanjutan.

Mengukur pertumbuhan yang diperoleh oleh perusahaan seringkali menjadi sesuatu yang sulit diwujudkan. Para wirausahawan acapkali kesulitan mengukur sejauhmana tingkat pertumbuhan yang dicapai selama menjalankan usaha. Subjektivitas dalam mengukur pertumbuhan usaha menimbulkan berbagai variasi pengukuran pertumbuhan.

Berdiri sejak 1992 hingga kini, kurang lebih 21 tahun, dan menjadi salah satu perusahaan yang kian maju di Sukaregang, PT ELCO dalah salah satu perusahaan yang masuk dalam kriteria ini.

Seorang pengusaha mungkin menganggap usahanya tumbuh karena melihat bukti fisik bangunan dan menambahnya peralatan, bertambahnya jumlah karyawan ataupun jumlah konsumen dan pelanggan meningkat. Sebagian pengusahamerasa berhasil dan tumbuh usahanya ketika dapat melepas sebagian besar apa yang dipikirkan dan dikerjakannya kepada para karyawannya.

Setelah wawancara mendalam ke Sukaregang, kita dapat ketahui bahwa pengusaha Sukaregang kian tahun kian berubah, baik ada yang terus berkembang meningkat, maupun ada yang melakukan kerjasama dengan pihak luar guna meneruskan usahanya yang melemah, akan tetapi dari sini kita ketahui bahwa usaha di Sukaregang ini kian berkembang baik perusahaan perintis maupun perusahaan yang telah cukup mapan.

Baum, Locke and Smith (2001:296) mengemukakan, "Three measure of venture growth: sales growth, employee growth and profit growth." Mengukur pertumbuhan usaha dapat dilakukan dengan tiga ukuran, yaitu: pertama, pertumbuhan penjualan; kedua, pertumbuhan karyawan dan ketiga, pertumbuhan keuntungan."

Pertumbuhan penjualan yang terjadi di sentra industri kulit Sukaregang kian meningkat dan terus berkembang, dibuktikan dengan data dari UPT, bahwa terdapat sekitar 323 perusahaan yang ada, dan mayoritas dari mereka sering meminjam fasilitas UPT, dikarenakan penjualan yang kian meningkat. Itu menjadi bukti bahwa pertumbuhan usaha penyamakan kulit Sukaregang.

Kuantitas masyarakat yang terbantukan dan direkrut perusahaan mapan maupun mendirikan usaha sendiri menunjukkan bahwa terjadi pertumbuhan karyawan di kawasan sentra industri kulit Sukaregang Garut ini.

Pertumbuhan keuntungan yang didapat oleh PT Elco sebagai contoh, menunjukkan bahwa keuntungan perusahaan adalah meningkat, sehingga masuk dalam teori Baum dan kawan-kawan ini.

Dimensi lain dalam menentukan batasan pertumbuhan dikemukakan Premaratne (2001:365), menurutnya, "mengukur pertumbuhan usaha kecil (small business growth) menggunakan kinerja penjualan dan kinerja profitabilitas."

Di Sukaregang ini banyak usaha perorangan yang bertumbuh, begitu pun profit yang didapatkan dapat menunjang kegiatan produksi yang kian meningkat, sehingga dalam dimensi ini Sukaregang dapat dikatakan sebagai usaha yang kian bertumbuh.

Wilson and Bates (2003:12) mengemukakan kriteria pertumbuhan usaha berkelanjutan sebagai berikut :

Pertama, continuing excellent service to customers yang ditunjukkan dengan pengulangan pembelian (generating repeat orders), retensi pelanggan (customer retention), rekomendasi dari pelanggan yang puas (referrals from satisfied customers) dan perolehan gross margin yang berkelanjutan (sustainable gross profit margins).

Dibuktikan pada saat di lapangan bahwa menurut pengusaha seringkali ada konsumen yang setelah mereka pertama kali membeli, mereka kembali lagi karena merasa puas dengan hasil kerja pengrajin dan penyamak kulit Sukaregang.

Kedua, efektivitas dan efisiensi operasi internal perusahaan (internal operations effectively and efficiently) yang ditunjukkan dengan biaya per unit yang terkontrol (control of unit costs) dan net margin yang memuaskan (satisfactory net margins). Hal ini dapat ditunjukkan dengan usaha para pengrajin dan penyamak Sukaregang yang mampu tetap survive dalam menjalankan usaha mereka. 
Ketiga, memiliki prestasi dalam mencapai keuntungan berkelanjutan (track record of sustained profitability). PT Elco disertai penjelasan di atas tadi menjadi tolak ukur salah satu pengusaha Sukaregang mampu mendapat prestasi yang cukup baik.

Keempat, memiliki kredibilitas yang cukup untuk meningkatkan pembiayaan eksternal (have sufficient credibility to raise the necessary finance externally)." Dibuktikan dengan banyaknya investor luar yang bekerja sama dan melakukan penambahan modal usaha untuk kesinambungan usaha di Sukaregang, yang kian tahun kian meningkat.

PT ELCO hanyalah salah satu perusahaan yang berkembang di Sukaregang. Selain perusahaan tersebut, masih banyak perusahaan yang berkembang dan mampu melakukan ekspansi penjualan secara nasional dan internasional. Berdasarkan informasi dari salah satu pengusaha kulit Sukaregang dan juga anggota Asosiasi Penyamak Kulit Indonesia, hasil produk Sukaregang sudah merambah pasar nasional seperti: Bandung, Bekasi, Jakarta, Surabaya, Medan dan lain-lain. Selin itu, menurutnya, sebagian produk sudah dipasarkan juga ke pasar internasional melalui distributor dan eksportir.

Berdasarkan hasil wawancara yang dilakukan peneliti, dari segi jumlah pengusaha, menurut informan dari Unit Pelaksana Teknis (UPT) Sukaregang, jumlah pengusaha naik dan turun berfluktuatif, ada yang meningkat hingga sukses kemudian turun, digantikan unit usaha lain yang sukses kemudian turun juga, terus berfuktuasi secara bergantian. Penyamak lokal Sukaregang jumlahnya makin lama semakin berkurang. Para penyamak lokal harus menghadapi kompetisi dengan pengusaha pendatang dengan kekuatan modal lebih besar.

Erik Wahyu Purwanegara, selaku Koordinator UPTD Balai Pengembangan Perindustrian Sub Unit Pengembangan IKM Penyamakan Kulit Garut mengemukakan, di Sukaregang ini industri ada mulai dari hulu ke hilir dan paling lengkap di Sukaregang ini. Industri Kecil Menengah (IKM) Penyamak ada 334, Jaket Kulit 173, sepatu ada 48, dan ada aksesoris dan lain-lain. Ada juga kulinernya ya seperti dorokdok dan kerupuk kulit, itu dari kulit sisa sebelum proses. Nah untuk kerecek itu kulit luar, ada lah sekitar 90-an industri seperti itu.

Proses dalam industri penyamakan kulit bertujuan untuk merubah kulit hewan menjadi lembaranlembaran kulit jadi yang siap digunakan sebagai bahan baku produk kulit seperti : sepatu, tas, kerajinan, dll.

Ketika awal perkembangannya, bisnis ini sempat menghasilkan keuntungan besar bagi pengusahanya karena belum banyak saingan. Namun, seiring dengan pertumbuhan jumlahnya, persaingan sering dikatakan tidak sehat lagi. Saat ini persaingan bukan lagi dari kualitas barang, tetapi pada harga sehingga sering terjadi saling banting harga antar sesama pengusaha.

Pimpinan UPT Sukaregang, beberapa pelaku usaha dan beberapa karyawan yang berhasil diwawancara mengemukakan hal yang senada terkait dengan hambatan-hambatan yang dihadapi oleh para pelaku usaha. Hambatan tersebut adalah masalah permodalan dan pasar. Mereka mengharapkan agar pemerintah membantu membuka pasar dan mempermudah permodalan. Dulu, pasar cukup baik karena konsumen datang sendiri ke tempat usaha mereka. Namun sejak krisis ekonomi, pendatang semakin sepi. Kalaupun ada yang datang, mereka hanya mencari barang yangmurah dan tidak terlalu memerhatikan kualitas. Selain tantangan untuk meningkatkan kualitas, kuantitas, dan membuka pasar, ada satu hallagi yang juga menjadi tantangan bagi para pengusaha kulit.

Selanjutnya yang menjadi pertanyaan besar dalam penelitian ini adalah, apakah hambatan-hambatan tersebut membuat perusahaan sulit tumbuh atau bahkan gulung tikar? Penulis mencoba menyajikan hasil interview dengan para pengusaha dan Unit Pelaksana Teknis (UPT) Sukaregang terkait dengan hal ini.

Hasil wawancara mengungkapkan bahwa secara umum tidak ada yang sampai mengalami kebangkrutan, yang ada adalah penurunan penjualan sehingga lama-kelamaan toko atau pabrik yang telah dibangun lama kelamaan menjadi kecil. Namun masih tetap bisa bertahan hingga sekarang. Dan apabila telah kesulitan usaha, mereka akan mencari penyokong modal yang lebih besar untuk diajak kerjasamasehingga usaha tumbuh kembali. Namun berdasarkan informasi dari UPT Sukaregang, tidak semua pelaku usaha bisa terus survive atau bertahan. Sebagian dari mereka ada yang menjual usahanya ke pengusaha lain.

Sebagaimana halnya dengan usaha kecil dan mengengah lainnya, para pelaku usaha di Sukaregang memiliki hambatan yang sangat klasik berupa modal usaha. Untuk memulai usaha ini, pengusaha membutuhkan modal besar. Dengan modal sekitar Rp 200 juta, pengusaha hanya dapat memiliki 4 buah molen dan dikategorikan sebagai pengusaha kecil. Namun, bisnis penyamakan kulit tidak harus memiliki mesin yang banyak. Pengusaha yang tidak memiliki modal peralatan yang cukup dapat menggunakan mesin milik pengusaha besar asal memberikan bayaran yang sesuai.

Menurut informasi dari UPT Sukaregang, selain mesin pengusaha pun harus membeli bahan-bahan kimia untuk proses penyamakan kulit. Bahanbahan tersebut sangat mahal karena sebagian besar masih impor dari Eropa. Menurut pegawai UPT Sukaregang, bahan-bahan impor tersebut porsinya bisa mencapai lebih dari separuhnya atau sekitar $60 \%$.

Pasar untuk industri ini masih sangat luas. Selain pasar internasional, pasar lokal dan nasional pun masih memiliki banyak peluang.. Namun, bagi pengusaha kecil masih sulit untuk mencari celahnya dan sulit mencari modal tambahan untuk memproduksi dengan kapasitas yang lebih besar.

Hal ini berbeda dengan kondisii pengusaha besar, gairah kebangkitan mulai terasa. Mereka mampu menjual hasil produksinya ke hampir seluruh tempat di Indonesia, bahkan sudah diekspor melalui perusahaan pengekspor ke beberapa destinasi ekspor seperti Australia, Singapura, Malaysia, dan Cina. 
Oleh karena itu, jika pemerintah daerah tidak serius melakukan pembinaan dan pelatihan terhadap para pengrajin kulit, dikhawatirkan produk kulit asli kawasan Sukaregang kab. Garut khususnya jaket kulit yang menjadi Trade Mark diambil alih oleh daerah lain yang juga menghasilkan produk yang sama dan ini jelas merugikan kabupaten Garut sendiri. Kurangnya pembinaan dan dukungan menyebabkan pengusaha pribumi kalah bersaing, dengan bukti banyak pengusaha luar yang datang.

Pengusaha Sukaregang menganggap bahwa mereka dapat bersaing dengan Thailand, yang mana dekorasi dan tata letak usaha diatur dan diperindah sehingga memanjakan dan membuat betah konsumen dalam berbelanja.

Terkait informasi dari Unit Pelaksana Teknis (UPT) ada kegiatan penyewaan alat untuk produksi sehingga UPT dapat menarik retribusi, yang mana pemanfaatan retribusi ini bekerja sama dan berkoordinasi dengan Asosiasi Penyamak Kulit Indonesia (APKI), yang mana adanya UPT ini membantu unit usaha kecil, yang biasanya Rp 1.700 per lembar di swasta sedangkan di UPT berkisar Rp 1.100 per lembar kulit. Begitu pun UPT turut membantu melaksanakan teknis di lapangan dengan memberikan informasi, turut membantu melakukan promosi, dan penyediaan konsultasi dan menyediakan link pembinaan, yang jumlahnya berkisar antara tiga hingga lima peserta per tahun.

Diketahui menurut pemerintah setempat, Asosiasi tidak berfungsi dengan baik dan solid, sehingga menyebabkan terkadang ada perbedaan pandangan dan pemikiran yang bercabang.Mengenai Corporate Social Responsibility (CSR), memang ada namun hanya satu dua perusahaan yang memberikan CSR yang baik, sedangkan di perusahaan lain manajemen perusahaannya tidak profesional. (salah satunya PT ELCO pimpinan Yusuf Tojiri yang memiliki CSR baik).

Salah satu perusahaan yang tumbuh dengan baik dan kontinyu di kawasan Sukaregang adalah PT Elco. Perusahaan dengan nama lengkap PT Elco Indonesia Sejahtera (PT EIS) merupakan industri dan perdagangan kulit samak (kulit domba dan kambing) berdiri pada tahun 1992, didirikan oleh Yusuf Tojiri.. Pada tahun 2000 terpilih sebagai Perusahaan Pasangan Usaha Berprestasi yang diberikan oleh PT Sarana Jabar Ventura Bandung, tahun 2002 terpilih sebagai Usaha Kecil Menengah Berprestasi Tingkat II Kabupaten Garut dan pada tahun 2003 terpilih sebagai Usaha Kecil Menengah Berprestasi Tingkat I Propinsi Jawa Barat. Pada tahun 2006 perusahaan berubah menjadi Perseroan Terbatas dengan nama PT Elco Indonesia Sejahtera. Dengan izin usaha industri No. 503/002/10/IND/IZ/2003 dan SIUP No.530/PK/ IZ/VIII/2005.P.

Sementara dari total itu, Elco mengambil pasar $30 \%$ dari total $70 \%$ pasar domestik untuk garmen dari bahan kulit tetap tersedia. Bahkan, pesanan dari luar negeri kerap datang.

Elco juga saat ini merupakan perusahaan industri yang mengolah bahan mentah (raw material) menjadi barang jadi (finishing goods), bahan mentah yang diolah berupa kulit mentah yang berasal dari domba, kambing dan sapi. Bahan mentah ini didatangkan dari berbagai daerah yang umumnya berasal dari Jawa Barat.

Berdasarkan paparan di atas, Sentra Industri Kulit Sukaregang mengalami pertumbuhan dengan berbagai macam kondisi terkait dengan ukuran usaha, permodalan, pasar dan dukungan pemerintah. Untuk beberapa kasus usaha dengan skala kecil terjadi fluktuasi pertumbuhan (naik-turun). Sedangkan untuk slkala menengah dan besar lebih kuat dalam menghadapi persaingan.

Padapembahasan selanjutnya, penelitimenyajikan gambaran pengelolaan usaha oleh para entrepreneur di Sukaregang dikaitkan dengan kepedulian mereka dalam menjaga kelestarian lingkungan hidup. Inilah yang menjadi hakikat ecopreneurship yang merupakan kemampuan wirausaha menumbuhkan usahanya sekaligus menjaga kelangsungan lingkungan hidup.

Proses Produksi dan Kualitas Lingkungan Hidup Pada Sentra Industri Penyamakan Kulit Sukaregang

Dari empat fungsi bisnis (marketing, produksi, SDM dan keuangan) yang dilakukan dalam mengelola dan menumbuhkan usaha di industri penyamakan kulit Sukaregang, fungsi produksi menjadi fungsi pengelolaan yang sangat terkait erat dengan kualitas lingkungan hidup di sekitar sentra industri ini.

Proses dalam industri penyamakan kulit bertujuan untuk merubah kulit hewan menjadi lembaranlembaran kulit jadi yang siap untuk dipergunakan menjadi bahan baku produk kulit seperti : sepatu, tas, kerajinan, dll. Proses dalam industri penyamakan kulit dapat dibagi menjadi 3 bagian yaitu : beamhouse process, tanhouse, dan finishing process.

Proses penyamakan kulit terdiri atas beberapa tahap pemrosesan. Tahap awal pemrosesan menggunakan mesin Molen dan mesin Splitting. Mesin Moln memiliki kemampuan mengolah sejumlah kulit mentah sekaligus dalam sekali proses sebagai sebuah batch. Ukuran batch dibatasi oleh kapasitas Mesin Moln. Sedangkan Mesin Splitting mengolah kulit lembar per lembar. Dengan demikian, pada proses penyamakan kulit mengalami dua jenis pemrosesan, pemrosesan secara batch pada mesin Molen dan secara job (lembar per lembar) pada mesin Splitting. Dengan perkataan lain, mesin Moln merupakan mesin pengolah batch (batch processing machine) dan mesin Splitting merupakan mesin pengolah job (discrete machine).

Tahapan-tahapan yang dilakukan dalam proses pengolahan kulit adalah sebagai berikut : 1). Sortasi dan penimbangan, Merupakan tahap persiapan kulit sebelum dilakukan proses penyamakan. Tahap ini merupakan tahap dimana kulit diseleksi untuk menetukan mana kulit yang layak untuk diproses. Setelah dilakukan seleksi maka kulit di timbang. 2). Proses perendaman (Soaking), Perendaman bertujuan untuk melemaskan kulit terutama kulir kering, 
sehingga mendekati kulit hewan yang baru lepas dari badannya. Perendaman juga bertujuan untuk membuang darah, feces, tanah dan bahan atau zatzat asing yang tidak hilang pada waktu pengawetan. Bahan yang digunakan adalah air, teepol, soda abu. 3). Proses pengapuran (Liming), Tujuan dari pengapuran adalah untuk membengkakkan kulit, mempermudah pembuangan bulu, epidermis dan lain-lain selama 24 jam. Bahan yang digunakan adalah air, natrium sulfida, kapur. 4). Proses buang daging (Fleshing), Kulit yang masih terdapat daging dihilangkan dengan pisau seset atau dengan mesin buang daging. 5). Proses pengapuran ulang (Relimming), Bertujuan untuk menghilangkan bulu dan zat-zat yang masih tertinggal pada kulit pada proses pengapuran. Bahan yang digunakan adalah air, dan kapur. 6).Proses buang kapur (Delimming), Proses buang kapur ini bertujuan untuk membuang sisa-sisa kapur, baik yang terikat maupun tidak terikat dalam kulit. Bahan yang digunakan antara lain air, ZA, H2SO4 yang telah diencerkan 10X dengan air. 7). Proses pengikisan protein (Bating), Proses ini bertujuan untuk memecahkan zat kulit dengan khemikalia yang mengandung protein. Bahan bating yang digunakan adalah oropon. 8). Proses pembuangan lemak (Degreasing), Bertujuan untuk membuang sisa-sisa lemak baik setelah pickle maupun sebelum proses penyamakan. bahan-bahan kimia yang digunakan antara lain iragol dan atau sandopan DTC. 9). Proses pengasaman (Pickling), Bertujuan untuk mengasamkan kulit pada $\mathrm{pH} 3-3,5$. Bahan pickle berasal dari asam-asam organik lemah seperti format dan laktat, selain itu juga menggunakan air, garam, $\mathrm{HCOOH}$ dan $\mathrm{H} 2 \mathrm{SO} 4$. 10). Proses penyamakan (Tanning), Tanning bertujuan untuk menghindari kekakuan dan kekerasan kulit, sehingga kulit tetap lemas ketika dalam keadaan kering dan dapat bertahan lama. Bahan-bahan yang digunakan dalam proses ini diantaranya adalah mimosa, krom, formalin, Na2CO3. 11). Proses penggantungan (Aging), Setelah proses tanning maka kulit akan mengalami proses aging, dimana kulit digantungkan di atas kuda-kuda kayu dan biarkan agak kering tanpa penjemuran dengan sinar matahari. Setelah itu kulit ditimbang dan di cuci selama 15 menit. 12). Proses netralisasi (Neutralization), Bertujuan untuk menetralkan asam bebas yang berada pada kulit. Bahan-bahan yang dipakai untuk netralisasi yaitu bahan-bahan yang bersifat alkalis. 13). Proses penyamakan ulang (Retanning), Penyamakan ulang dimaksudkan untuk memberikan sifat unggul yang lebih baik yang dimiliki bahan penyamak lain. Bahan yang digunakan dalam proses ini adalah bahan penyamak sintesis, nabati atau mineral. 14). Proses pewarnaan dasar (Dyeing), Proses ini bertujuan untuk memberikan warna dasar pada kulit tersamak agar dapat memperindah penampakan kulit jadi. Bahan yang digunakan antara lain air, leveling agent, cat dasar, asam formiat. 15). Proses peminyakan (Fat Liquoring), Proses peminyakan bertujuan untuk mendapatkan kulit samak yang lebih tahan terhadap gaya tarikan atau gaya mekanik lainnya, disamping itu untuk menjaga serat kulit agar tidaklengket satu dengan lainnya, sehingga kulit lebih lunak dan lemas. Bahan yang digunakan adalah air, minyak sulphonasi dan ditambahkan anti jamur. 16). Proses fixasi (Fixation), Proses ini bertujuan untuk memecahkan emulsi minyak dan air sehingga airnya mudah menguap pada saat dikeringkan. Bahan kimia yang digunakan adalah $\mathrm{HCOOH}$ yang telah diencerkan 10X dengan air, dan ditambahkan anti jamur. 17). Proses pengeringan (Drying), Tujuan dari proses pengeringan ini adalah mengurangi kadar air bebas di dalam kulit secara bertahap tanpa merusak kulit, zat penyamak dan minyak yang ada di dalam kulit, caranya dengan menggantung kulit pada kuda-kuda kayu dan diangin-anginkan. 18). Proses penyelesaian, Pada proses ini kulit di beri binder, pigment, penetrator, filler, wax, thinner atau lack sesuai dengan tujuan penggunaan kulit samak tersebut. Kulit yang telah di cat dan dikeringkan lalu disetrika atau diembosh untuk memberi motif pada permukaan kulit dan memperindah penampakannya.

Proses produksi yang diuraikan di atas, menggunakan bahan kimia yang membahayakan jika tidak ditangani denganbaik. Protes punmulaibermunculankarenabanyak warga di daerah hilir sungai yang mengalami gangguan kesehatan kulit. Persoalan limbah ini memunculkan ide dan rencana-rencana untukmengantisipasi peningkatan jumlah limbah yang dibuang ke sungai.

Keberadaan industri penyamakan kulit Sukaregang di Kota Garut memberikan dampak negatif terhadap pencemaran lingkungan sekitarnya, terutama pencemaran terhadap air sungai. Terkait isu lingkungan, menurut informan yang juga sebagai salah satu anggota Paguyuban Pengrajin Kulit dan Asosiasi Penyamak Kulit Indonesia, bahwa isu lingkungandi Sukaregang bukan hanya menjadi isu lokal, daerah, bahkan telah menjadi isu nasional, dan diketahui bahwa pihak luar seperti Unesco juga LSM-LSM luar banyak yang mengecam. Warga Sukaregang menyadari Instalasi Pengolahan Air Limbah (IPAL)tidak hanya tanggung jawab sepihak. Di Sukaregang ini ada 4 IPAL yang dibangun dan aliran pembuangan limbah ini sudah diatur jalurnya,akan tetapi IPAL bantuan dari propinsi pengelolaannya kurang optimal. Ada dua alur yang termasuk jalur IPAL ini, yang dari Sungai Cigulempang dan Sungai Ciwalet, keduanya berujung ke sungai Cimanuk.

Berdasarkan suatu hasil temuan Priyanto (2006:217), air limbah dari hasil penyamakan kulit mengandung zat yang berbahaya yaitu kromium (Cr(VI) dan kromiun total.

Kandungan krom yang melebihi ambang batas ini terjadi dikarenakan industri penyamakan kulit masih mengandalkan empatIPAL yang tidak berfungsi optimal pada kawasan industri tersebut. Keempat IPAL tersebut hanya berfungsi sebatas kolam penampungan saja, sedangkan untuk pengolahan logam berbahaya dan senyawa berbahaya lainnya tidak dilaksanakan karena menurut Dinas Lingkungan setempat bahwa untuk pengoperasian empat IPAL ini membutuhkan 
dana yang relatif besar, yaitu mencapai 1.7 milyar dan pemerintah setempat tidak dapat menganggarkan dana sebesar itu.

Sebagai upaya untuk memecahkan masalah lingkungan yang dihadapi kalangan industri tersebut, maka strategi end-of-pipe treatment yang kerap digunakan oleh pihak industri dan pemerintah setempat sudah tidak tepat lagi. Strategi pengelolaan lingkungan yang secara sistematis cocok dan tepat diterapkan oleh pemilik perusahaan saat ini adalah Pollution Prevention atau lebih dikenal dengan nama Cleaner Production (Produksi Bersih).

Mengenai kualitas air tanah, menurut salah satu warga lebih dari 6 meter masih bagus begitupun air dari sumur bor. Tapi air tanah dengan kedalaman kurang dari 6 meter sudah tercemar. Masih menurut warga sekitar pabrik, untuk air dari sumur dangkal, sudah tidak bisa saya buat untuk air minum. Hanya dipakai untuk mencuci dan mandi saja. Sehingga ada asumsi bahwa Sukaregang ini kualitas airnya terburuk di Indonesia, sama halnya seperti di Majalaya, Kabupaten Bandung. Sehingga untuk keperluan air minum menggunakan air dari gunung.

Sedikitnya 6.000 meter kubik Limbah Bahan Berbahaya dan Beracun (B3) perhari yang dihasilkan dari kawasan industri penyamakan kulit Sukaregang Kecamatan Garut Kota, Kabupaten Garut.

Menurut Badan Pengelola Lingkungan Hidup (BPLH) Kab. Garut, selama setahun dari limbah B3 ini bisa mencapai 1,97 juta meter kubik di kawasan Kulit Sukaregang, karena diindikasikan masih saja sejumlah pengusaha yang tidak memperhatikan aspek lingkungan terhadap pengelolaan IPAL. Sebab lainnya, para pengusaha penyamakan kulit dikawasan tersebut merasa pengelolaan IPAL dinilai masih berat dan memerlukan biaya yang cukup tinggi. Sehingga lahan IPAL yang seharusnya sebagai salah satu syarat tak mampu disediakan oleh para pengusaha sendiri.

Buangan limbah cair industri penyamakan kulit Sukaregang langsung tanpa melewati IPAL (Instalasi Pengolahan Air Limbah) pada dua sungai yang mengalir ke Cimanuk yaitu sungai Cikedok dan sungai Cilongkang. Padahal limbah buangan penyamakan kulit adalah termasuk limbah kimia B3 yang keras dan berbahaya bagi kesehatan manusia.

Jika kemarau tiba sungai mengalami kekeringan, limbah mengendap dan menyebabkan bau sehingga menggangu masyarakat sekitar. Banyak masyarakat yang mengajukan komplain.Terkadang asosiasi dan paguyuban sering berembuk dan melakukan kerja bakti.Ada kompensasi dari pengusaha kepada masyarakat sekitar. Seperti pemberian daging kurban saat Idul Qurban. Begitu pun ada beberapa nominal uang yang diberikan, akan tetapi tidak semua nya memberikan, hanya orang perorang. Ada yang satu pengusaha memberi kompensasi optimal, namun ada juga yang sekedarnya.

Mengacu kepada pendapat Schaltegger (2002:2) yang mengisyaratkan bahwa seorang ecopreneur harus mampu mereduksi atau meminimalisis dampak negatif dari operasi usahanya terhadap keberlangsungan lingkungan hidup, maka dapat dikatakan bahwa para pengusaha penyamakan kulit di Sukaregang secara umum belum mampu melakukannya dengan baik. Pertumbuhan usaha yang selalu diupayakan oleh para pelaku usaha belum seimbang dengan upaya melestarikan lingkungan dengan baik.

\section{Pengelolaan Limbah Industri Penyamakan Kulit}

Masalah limbah jadi persoalan usaha penyamakan kulit di Garut, Jawa Barat saat ini masih memiliki permasalahan yang sama. IndustriPenyamakan Kulityang menggunakan proses Chrome Tanning menghasilkan limbah cair yang mengandung Krom. Krom yang dihasilkan adalah krom bervalensi 3+ (trivalen). Limbah cair maupun lumpurnya yang mengandung Krom Trivalen ini dapat membahayakan lingkungan karena Krom Trivalen dapat berubah menjadi Krom Heksavalen pada kondisi basa yang merupakan jenis limbah B3 yang dapat membahayakan bagi kesehatan.

Menurut pimpinan UPTD, terkait lingkungan hidup tersebut, sebenarnya tupoksinya dari Badan Lingkungan Hidup Garut, akan tetapi penangannya belum optimal. Terkait hal ini pun melalui BPLH, dan paguyuban juga APKI rencananya akan melakukan revitalisasi tempat-tempat yang ada. APKI akan berkoordinasi dengan Lingkungan Hidup.

Menurut Tojiri, salah satu pengusaha kulit, dibutuhkan sekitar Rp 5 miliar untuk mengolah limbah buangan penyamakan kulit di sentra Usaha Penyamakan Kulit, Sukaregang, Garut. Hal ini juga dibenarkan oleh para pengusaha dan pihak UPTD. Pengelolaan limbah cair melalui IPAL dibutuhkan anggaran sebesar Rp. 6 juta pertahun/perusahaan atau sedikitnya Rp. 500 ribu biaya yang dikeluarkan oleh perusahaan per bulannya. Sementara, jumlah pengusaha penyamakan kulit di kawasan Sukaregang mencapai 300 perusahaan yang menghasilkan 3 ton perbulan kebutuhan kulit.

Meski demikian, pihak pemerintah daerah mengakui pihaknya memiliki keterbatasan dalam penyediaan fasilitas pengelolaan limbah cair IPAL, dikarenakan para pengusaha kulit di kawasan itu belium bisa melepaskan ketergantungan operasionalnya terhadap pemerintah sendiri. Bahkan, sejumlah aset pemerintah yang telah disediakan banyak berubah fungsi dari para pengusaha. IPAL yang dibangun oleh pemerintah dijadikan kolam ikan.

Dalam membentuk dan menumbuhkan kemampuan para pengusaha dalam hal ecopreneurship, tidak dapat lepas dari kebijakan pemerintah. Pemerintah dan pengusaha harus bersatupadu dalam menjaga lingkungan hidup. Schaper (2002:4) mengemukakan

"Legislation, government regulation and industrisupport agencies all have a role to play in shaping the way that business conducts its activities. Mengacu kepada pendapat tersebut maka ecopreneurs di Sukaregang juga akan bermunculan apabila badan legislasi, pemerintah dan kalangan pelaku industri bekerjasama membangun lingkungan hidup.

Selain itu juga, stakeholder lainnya, seperti kelompok pelobi, NGOs, lembaga pemberi modal, 
asosiasi industri and komunitas lokal Schaper (2002:4) merupakan pihak-pihak yang ikut membentuk para entrepreneur yang berwawasan lingkungan.

Untuk mengatasi ini, berdasarkan informasi dari pimpinan UPTD dan BPLH, dapat dilakukan dengan penerapan clean product. Produk bersih yang dimaksud adalah produksi ramah lingkungan. Hal ini dapat dilakukan dengan cara menghemat pengeluaran limbah dan menghemat pemakaian zat kimia. Selain itu juga dapat dilakukan pemisahan krom. Krom dapat dipisahkan dari cairan buangan dengan cara mengendapkan kembali sebagai Krom Hidroksida dengan jalan penyaringan yang kemudian di daur ulang dengan cara sbb: Air buangan dari penyamakan kromdan air pencucian (sebanyak 2 x 100\% air) yang sudah bebas dari padatan diberi larutan magnesium hidroksida, dan diendapkan kira-kira 10 jam, yang kemudian cairan dipindahkan ke bak lain (dengan pipa penyedot, tetapi jangan sampai endapannya ikut tesedot). Cairan tersebut bila benar-benar bebas dari endapan akan mengandung Krom kurang dari 2 ppm sehingga bisa langsung dibuang atau dipakai untuk daur ulang.

Pengusaha Sukaregang terus menerus mencoba memecahkan solusi tentang bagaimana mengolah limbah dan pencemaran lingkungan dengan cara yang seefektif mungkin dan seefisien mungkin, akan tetapi hal tersebut selalu saja ada kendala serta masalah yang ada. Sehingga manajemen bisnis yang ada tidak mampu mencapai tujuan yang berwawasan lingkungan, dan keinginan untuk menjadi green business menjadi tidak tercapai, karena keterbatasan tadi.

Pernyataan tersebut menggambarkan bahwa konsep green entrepreneur merupakan tanggung jawab dari semua stakeholders dalam mewujudkannya. Dalam hal ini, baik pemerintah setempat hingga pemerintah propinsi, pengusaha setempat, masyarakat sekitar yang diwakili oleh tokoh masyarakat Sukaregang telah mencoba untuk duduk bersama mendiskusikan tentang bagaimana dampak dari pencemaran lingkungan ini dan bagaimana bahwa pengolahan limbah dan proses produksi di Sukaregang ini dapat terlaksana sesuai dengan konsep yang lebih ramah lingkungan, akan tetapi kembali terkendala dalam pengelolaan yang kurang maksimal dan keterbatasan dana yang kembali dimasalahkan.

Seorang ecopreneur adalah pengusaha yang mampu menyeimbangkan antara pertumbuhan usaha dan perkembangan lingkungan hidup. Seorang entrepreneur harus mampu mereduksi atau meminimalisis dampak negatif dari operasi usahanya terhadap keberlangsungan lingkungan hidup. Salah satunya kita ambil PT ELCO sebagai ecopreneur yang cukup memperhatikan lingkungan, mengingat mereka memikirkan tentang bagaimana proses produksi dan limbah yang dihasilkan bisa lebih ramah lingkungan.

\section{SIMPULAN}

Sebagian besar pengusaha Sukaregang belum sepenuhnya mampu untuk menerapkan kewirausahaan berwawasan lingkungan (ecopreneurship) dalam menumbuhkan usahanya. Hal ini dikarenakan dalam pengolahan limbah yang baik dan benar membutuhkan biaya yang besar dan dukungan dari semua stakeholder.

Pertumbuhan penjualan yang terjadi di sentra industri kulit Sukaregang kian meningkat dan terus berkembang, yang dindikasikan oleh data dari UPTD bahwa terdapat lebih dari 300 perusahaan yang ada, dan mayoritas dari mereka sering meminjam fasilitas UPTD, dikarenakan penjualan yang kian meningkat. Itu menjadi bukti bahwa pertumbuhan usaha penyamakan kulit Sukaregang. Pertumbuhan ini juga ditandai dengan luasnya pasar baik yang bersifat lokal, nasional maupun internasional.

Namun demikian pertumbuhan usaha yang dicapai belum disertai dengan pengelolaan lingkungan hidup yang memadai. Hal ini ditandai dengan kandungan limbah berbahaya yang mencemari air dan udara di kawasan Sukaregang. Walaupun ada beberapa perusahaan yang sudah mampu melakukan penaganan dengan baik, namun untuk usaha skala kecil belum mampu melakukan pengolahan limbah dengan baik. Dukungan pemerintah Kabupaten Garut dalam pengelolaan limbah pun masih terbatas.

\section{DAFTAR PUSTAKA}

Barringer, B. R., Jones, F. F., \& Neubaum, D. O., (2005). "A quantitative content analysis of the characteristics of rapid-growth firms and their founders", Journal of Business Venturing, 20(5): $663-687$

Baum, J Robert, Locke, Edwin A and Smith Ken G.A Multidimentional Model of Venture Growth. The Academy of Management Journal Vol. 44, No. 2 (Apr., 2001), pp. 292-303

Katz, Jerome A and Green, Richard P. 2008. Entrepreneurial Small Business. USA : McGrawHill International

Wilson, Peter and Bates, Sue.2003. Small Business Growth. England : Jhon Wiley \& Sons Ltd

Jamaluddin, Askiah, Carolyn Dickie. 2011. Decisionmaking Related to Business Growth: Malay Small Business in Selangor. International Journal of Business and management Vol 6 No 10; October 2011.

Premaratne, Sandaran P. 2002.Entrepreneurial networks and small business development. Eindhoven :TechnischeUniversiteit Eindhoven

Priyanto, Budhi, 2006.Uji Toksisitas Limbah Penyamakan Kulit Menggunakan Metode Pengjambatan Pertumbuhan Lemna sp. Jurnal Teknik Lingkungan. Jakarta. Vol.7, hal: 212-218

Robson, Paul J. A, Robert J. Bennett. 2000. SME Growth: The Relationship with Business Advice 
and External Collaboration. Journal Small Business Economics 15: 193-208.

Schaper, Michael. 2002. The Essence of Entrepreneurship. Australia:Greenleaf Publishing

Schaltegger, Stefan .2002. Framework for Ecopreneurship. Australia ::Greenleaf Publishing
Wiklund, Johan, Holger Patzelt, dan Dean A. Shepherd. 2009. Building an Integrative Model of Small Business Growth. Small Business Economy, Vol. 32, No. 4, 351-374

\section{Sumber Lain :}

Data Sekunder, Disperindagkop Kab Garut Data Sekunder, UPTD Instalasi Pengembangan IKM Penyamakan Kulit Garut 